\title{
BUSINESS MODEL FINANCIALLY VIABLE FOR A RADIO FREQUENCY IDENTIFICATION APPLICATION TO HALAL FOOD SUPPLY CHAIN TRACEABILITY SYSTEM
}

\author{
Artya Lathifah \\ Program Studi Teknik Logistik, Fakultas Teknologi Industri dan Agroindustri, \\ Universitas Internasional Semen IndonesiSa \\ E-mail : artya.lathifah@uisi.ac.id \\ Winda Narulidea \\ Program Studi Teknik Logistik, Fakultas Teknologi Industri dan Agroindustri, \\ Universitas Internasional Semen Indonesia \\ Winda.narulidea@uisi.ac.id
}

\section{ARTICLE HISTORY}

Received :

30 December 2016

Accepted :

16 June 2017

Online Available :

30 June 2017

Keywords: Halal Supply Chain integrity, RFID, Traceability
Financial viable,

\section{ABSTRACT}

Recently, the halal concept has acquired a raising attention. This is as a result of the number of global Muslim population increasing annually. Halal concept has become more popular since Halal food consumers more aware and concern about the integrity of Halal status. Consumers also inquisitive about all the activities involved along the supply chain whether the products that they purchased were truly Halal. In order to accomplish the intent to further develop halal sector, something need to be done to introduce a comprehensive and suitable tracking and tracing technology for the sustainability of the halal product integrity. So, a proper technological framework that can support the entire supply chain of halal product process is needed. This paper discusses a financially viable business model for a Radio Frequency Identification (RFID) application to a halal food traceability system. We use a case study of RFID implementation in the chain of convenience stores from previous research. RFID will give benefits for integrity of the Halal Supply Chain by branding of the trustworthy of the "Halal" itself. For the economic aspect, RFID give advantage not only in responsess to the product availability and customer's satisfaction but also real time information about demand.

\footnotetext{
Kata Kunci :

Kelayakan

Financial, Integritas Rantai Pasok Halal, RFID, Pelacakan
}

\section{ABSTRAK}

Akhir-akhir ini konsep halal mendapat perhatian. Salah satu penyebabnya jumlah populasi Muslim global yang meningkat setiap tahunnya. Konsep halal telah menjadi semakin populer karena konsumen makanan halal semakin sadar dan peduli terhadap integritas status halal. Konsumen juga ingin tahu tentang semua 
aktivitas yang terlibat di sepanjang rantai pasokan apakah produk yang mereka beli benar-benar halal. Untuk mencapai tujuan untuk pengembangan sektor halal lebih lanjut, perlu dilakukan pengenalan teknologi pelacak dan penelusuran komprehensif dan sesuai untuk keberlanjutan integritas produk halal. Jadi, teknologi yang tepat yang bisa mendukung keseluruhan supply chain proses produk halal sangat dibutuhkan. Makalah ini membahas model bisnis yang layak secara finansial untuk aplikasi Radio Frequency Identification (RFID) ke sistem ketertelusuran makanan halal. Kami menggunakan studi kasus implementasi RFID di rangkaian convenience store dari penelitian sebelumnya. RFID akan memberi manfaat bagi integritas Rantai Pasokan Halal dengan memberi merek kepercayaan dari halal itu sendiri. Untuk aspek ekonomi, RFID memberi keuntungan tidak hanya karena respons terhadap ketersediaan produk dan kepuasan pelanggan namun juga informasi real time mengenai permintaan.

\section{INTRODUCTION}

The word of "Halal" interprets as permitted, allowed, authorized, approved, sanctioned, lawful, legal, legitimate or licit. Islam places a very strong emphasis on cleanliness in everything. For example, before performing our daily prayers, ablution, as means of cleansing ourselves, is absolutely, and must be completed in the correct way. Then, the cleanliness concept is also enlarged to other things, especially in the context of foods and beverages. The food and beverage integrity, associated services and information should be guaranteed, because product (food) integrity issue is the same with product (food) safety issue. According to Beulens, Broens et al. (2005), food safety is currently considered as an important issue for all stake holders in food production. This issue is including food safety, healthy, nutritious and quality. Integrity of halal food should be monitored so that users can satisfy with the authenticity of halal products (Muhammad NM, 2009).

The halal concept has obtained increasing attention recently. As a result demand with halal certification has increased. This is due to the rising number of Muslim population globally, which is approximately 1.8 billion. Halal food products are the main and most recognized components of the Halal industry. It is no longer viewed as solely religious requirements for the Muslim communities but the non-Muslims have also started to demand for this particular food group due to the perception that Halal foods are much more clean, hygiene and tasty (Abdul Talib, Mohd Ali \& Jamaludin 2008; Belkhatir, Bala \& Belkhatir 2009). The halal food market is currently worth $16 \%$ of the entire global food industry and could account for $20 \%$ of world trade in food products in the future which account respectively Asia (63\%), Africa (24\%), and Europe (10\%) of the global market (Spiegel et al, 2012). The increasing more apparent when we consider at rate of 
population growth in Muslim and non muslim majority countries. The global Muslim population in 2010 was estimated at 1.7 billion (24\% of the world's population), and it is expected to increase to 3.3 billion (29\% of the world's population) by 2050 (Kettani 2010). The demand growth also corresponds with increasing purchasing power among Muslims globally (Lodhi, 2010). With a halal trade of currently less than $10 \%$ of global trade, halal promises an attractive market segment for food, pharmaceuticals, and cosmetics industries (Jan, 2012). With per capita expenditure on food and beverages consistently on the rise, especially throughout the Muslim world, the estimated value for halal products has reached to several hundred billion USD annually. The significance of food supply and particularly the supply of halal foods become more apparent when we look at the magnitude and rate of population growth in Muslim and non-Muslim majority countries (Yousef, 2010). Following this trend, the "halal food" has appealed to global food producers consideration.

According to the researchers (Christopher, 1988; Van Amstel \& Van Goor, 2001; van Assen et al., 2010) as cited by Tieman (2012) halal needs a supply chain approach where the value chain and its supply chain activities totally align with the Syariah Law. In Halal food supply chain, the main goal is not only to ensure that satisfaction of the customer is achieved, but also to ensure that the Halal status of the food product remains intact throughout the whole process of the supply chain (Bahrudin, Illyas \& Desa 2011) as cited by Zulfakar et al (2014). The integrity of the Halal food product must be protected by all means and all necessary steps must be taken by all parties involved in the supply chain to avoid any cross contamination that will lead to product becoming non-Halal, or Haram. The food products must not only be Halal at the supply chain starting point but throughout the supply chain until it reaches its final destination. Therefore, we need to introduce a comprehensive and appropriate Tracking and Tracing Technology to maintain halal product integrity and develop a technological framework that can support the entire Halal Product Supply Chain (Tieman, 2014).

An RFID system is based on tags and readers (Tajima, 2007), the tag is a microchip and an antenna that stores and transmits identification data, and the reader communicates with the tags, delivering the information in a digital format to a database. In addition, retailers may equip kiosks for consumers' inquiries about the food distribution information.

RFID technology developed for several decades, with successful applications for access control systems, airport baggage handling, livestock management systems, and automated toll collection systems, especially in logistics and retail businesses (Ergen et al., 2007; Agarwal, 2001; Hou and Huang, 2006; Kelly and Erickson, 2005) as cited by Hong I-Hsuan et al (2011). Some researches shows that RFID technology helps retail companies both build up the product availability and enhance a chain's end-to-end visibility. For example, a construction industry application using RIFD in an automated traceability system of pipe 
spools and buried assets is another successful application of the technology. Tajima (2007) suggests that adopting RFID in supply chain management may reduce management costs and increase the efficiency of product flows. The food industry's accuracy and speed of gathering source information can be increased if RFID technology is applied (Mc Meekin et al., 2006). Meuwissen et al. (2003) indicate the importance of the traceability system and analyze its potential costs and benefits by applying RFID technology to the British livestock industry. Wamba et al. (2008) shows that using RFID in a retail industry can improve shipping, receiving and put-away processes corresponding to suppliers, distribution centers (DCs) and retailers, respectively. Gandino et al. (2007) creates a fruit warehouse's traceability system based on RFID technology.

We made illustration in financial investment and installation of RFID for Halal integrity in the supply chain. The associated technology, learning and management skills will be transferred to an application service provider (ASP) which will consult with the parties intending to launch a Halal food traceability system. The aims of this paper are to analyze the profitability and benefits incurred in establishing the ASP and to propose a financially viable business model of a Halal food traceability system.

In this paper, we used dataset from Hong I-Hsuan et al (2011) which was a pilot study for traceability food-chains in Taiwan's convenience store. Their project was to improve food safety in Taiwan. They use 3 parties of the supply chain (manufacturer, DCs, and retailer). This paper add some new parties which are: raw material (supplier) and transportation and new scheme of the year promotion (5 year and 7 year). The aim of the pilot project is to provide industry practitioners and government regulators with a costbenefit analysis such that associated firms in food supply chains may be willing to implement a Halal food traceability system in the future. We hope to contribute significantly to the ongoing discussion among industry, regulators and consumers.

\section{LITERATURE REVIEW}

\section{Traceability System \\ Food Traceability System}

According to Bahrudin et al (2011) traceability is define as the ability to trace the history, application or location of what is under consideration according of The International Organization for Standardization (ISO). Traceability is a series of recorded identifications. In order to achieve the traceability concept, a traceability technology needs to be included and imply in the supply chain. Radio Frequency Identification (RFID) is a suitable technology that can track and trace, forward and backward history of a data. The aim of this research is to analyze legal and regulatory aspects of halal food traceability, and to provide a strategic technological framework that can support the entire Halal Supply Chain Process with tracking and tracing technology. Possible technical resources were clarified by analyzing 
Business Model Financially ...

assessment criteria obtained from studies of radio frequency identification (RFID) technology.

\section{Operations in the food tracking and tracing system}

Table 1

Detail of Proposed Technological Halal Supply Chain Framework

\begin{tabular}{|c|c|c|}
\hline Add-on & \multirow{2}{*}{ Syariah Law } & \multirow{2}{*}{ Integrated System } \\
\hline Stage & & \\
\hline \multirow{2}{*}{ Raw Material } & Livestock being feed with good, clean, permitted and legal nutritious food & \multirow{2}{*}{ Monitoring System } \\
\hline & Slaughter according to Islamic guidelines & \\
\hline \multirow{2}{*}{ Inbound Logistic } & Monitoring the flow of inbound vehicle (truck/container) & Monitoring System \\
\hline & If needed, doing samak to certain truck or container & Inventory System \\
\hline \multirow{2}{*}{ Food Manufacturer } & \multirow{2}{*}{$\begin{array}{l}\text { Repackaging by production house, using halal equipment and worker } \\
\text { practice the concept of hygiene permitted by Islamic law }\end{array}$} & Monitoring System \\
\hline & & Inventory System \\
\hline \multirow{2}{*}{ DC } & \multirow{2}{*}{ Monitoring the halal product from mixed up with non-halal product } & Monitoring System \\
\hline & & Inventory System \\
\hline \multirow{3}{*}{ Outbound Logistic } & Monitoring the flow of inbound vehicle (truck/container) & Monitoring System \\
\hline & If needed, doing samak to certain truck or container & \multirow{2}{*}{ Inventory System } \\
\hline & Need to do segregation in the container if there is non-halal and halal produd & \\
\hline \multirow{2}{*}{ Retail and Shop } & \multirow{2}{*}{ Maintained the freshness, cleanlines and product safety to be sold } & Monitoring System \\
\hline & & Inventory System \\
\hline
\end{tabular}

Source : (Bahrudin et al, 2011)

Table 1 shows the detail of category in Technological Halal Supply Chain Framework by it stage (raw material, producers, warehouse, transportation, Distribution Center, and Retailer), every stage in Proposed Halal Supply Chain Framework have been modified by imply RFID technology to complete the needs. As shown, every detailed of category add-on such as Syariah law, RFID technology and integrated system is list in the table.

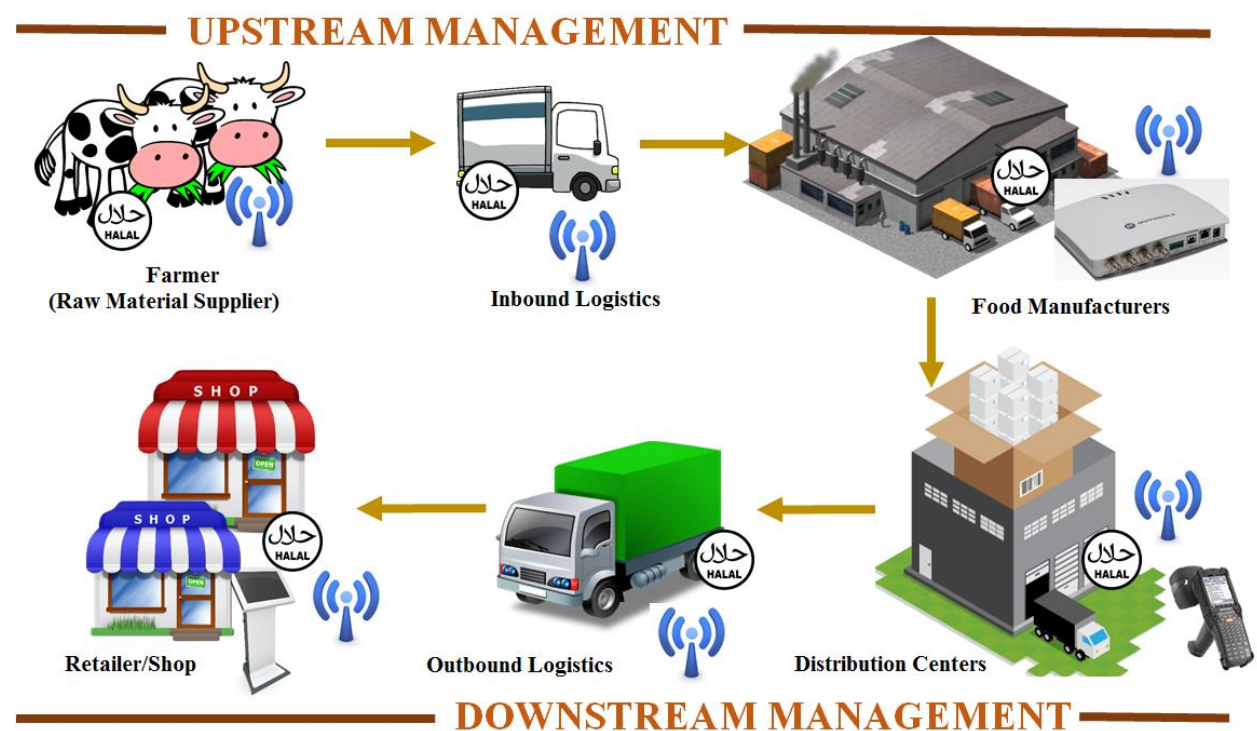

Figure 1

Technological Halal Supply Chain Framework 
According to Hong I-Hsuan et al (2011) each retailer is equipped with at least one hand-held reader to record inventory, two RFID-POS systems at two checkout counters and one kiosk per store for customers to inquire about goods. The supplier (raw material provider) completed with two fixed and one hand held reader. Each food manufacturer has at least one hand-held and two fixed readers to record production, transportation processes (inbound and outbound) has at least one fixed reader and each DC has one hand-held and two fixed readers. The estimated total quantities in Table 5 should give RFID component manufacturers strong incentives to develop hardware for this potentially large market.

The types of information collected from the stores and DCs in our case study, based on estimating the total readers, RFID-POS and kiosks required by the members in the chains with good experience in electronic commerce systems are as follows: number of retailers 9200, DC's 45, raw material supplier 60, transportation 60, and food manufacturers 30 (data are used by Industrial Technology Research Institute)

Table 2

Estimated hardware demand for the chains of convenience stores.

\begin{tabular}{|c|c|c|c|c|}
\hline & Fixed Reader & $\begin{array}{c}\text { Hand Held } \\
\text { Reader }\end{array}$ & $\begin{array}{c}\text { RFID-POS } \\
\text { Systems }\end{array}$ & KIOSK \\
\hline Raw Material & 120 & 60 & N/A & N/A \\
\hline Inbound Logistic & 30 & N/A & N/A & N/A \\
\hline Production & 60 & 30 & N/A & N/A \\
\hline Storage/DC & 90 & 45 & N/A & N/A \\
\hline Outbound Logistic & 30 & N/A & N/A & N/A \\
\hline Retail and Shop & N/A & 9200 & 18400 & 9200 \\
\hline
\end{tabular}

\section{ANALYSIS AND DISCUSSION}

\section{Financial Plan Of Implementing Rfid Technology}

Hong I-Hsuan et al (2011) stated that the innovation diffusion theory (Kotler, 1994) is to predict the number of adopters of RFID technology in food supply chains. Innovation diffusion theory is widely used to understand technology adoption in organizations (Ranganathan and Jha, 2005; Lee and Shim, 2007; Sharma et al., 2008 as cited Hong I-Hsuan et al (2011)). Rogers (1995) indicates that it follows an S-shaped cumulative curve where the number of members adopting a new technology is plotted over time on a frequency basis. The cumulative function of the logistic distribution is used as a growth curve (Balakrishnan, 1992) the cumulative distribution function ( $c d f)$ of the logistic distribution with variable $x$. The probability density function (1) and the cumulative distribution function (2) of the standard logistic distribution is taken from Hong I-Hsuan et al (2011) 
Business Model Financially ...

$$
\begin{aligned}
& F(x)=\frac{1}{\left(1+e^{-x}\right)}, x \in R \\
& F(x)=\frac{e^{-x}}{\left(1+e^{-x}\right)^{2}}, x \in R
\end{aligned}
$$

The plants of each supplier, food manufacturer (including inbound and outbound logistics or transportation) and the DCs install the RFID hardware at initiation, followed by a large number of retailers. Because time is needed to promote RFID technology to the entire food supply chain, we assume that retailers will adopt RFID following an S-shaped cumulative curve in $T$ periods according to the innovation diffusion theory, which has been applied in (Norton and Bass, 1987 and Schmittlein and Mahajan, 1982). Therefore, let $K, M$, $N$, and $L$ denote the total numbers of supplier of raw material, food manufacturers (including transportation inbound and outbound), DCs, and retailers, respectively. The transportation (inbound and outbound) is attached as the part of food manufacturers.

Then, we analyze the costs and profits of the ASP. The the financial analysis is not consider in this paper, since the procurement cost of the RFID hardware is simply transferred to the members installing the traceability system. One pricing approach is breakeven pricing. Breakeven analysis is used to identify the sales volume at a price that covers costs, where the total revenues equal the total costs of all fixed and variable costs. We adopt the formula from (Bahrudin et al, 2011). In (3), the breakeven point is the minimum sales that must be sold before a firm starts to make a profit.

$$
\begin{aligned}
& \text { Sales Volume }=\frac{\text { Fixed Costs }+ \text { Desired Profit }}{\text { Price }- \text { Unit Variable Cost }} \\
& \text { Price }=\frac{\text { Fixed Costs }+ \text { Desired Profit }}{\text { Sales Volume }- \text { Unit Variable Cost }}
\end{aligned}
$$

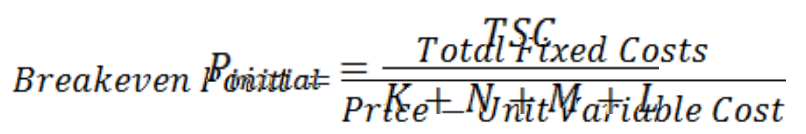

To establish a company would incur start-up costs in the beginning and operation costs which maintain the company existence. As a result, we assume the ASP incurs start-up and regular operations costs for promoting RFID technology. The start-up costs only occur in the initial period, and operations costs are considered in the following periods. The start-up costs include fixed assets costs, such as office supplies and installation of hardware, and the operations costs include rent, payroll, insurance and utilities. Let $T C_{t}$ denote the total cost in period $t, T S C$ the total start-up costs, and $T O C_{t}$ the total operations cost in period $t$.

$$
T C_{t}=\left\{\begin{array}{cc}
T S C+T O C_{t}, & t=1 \\
T O C_{t} & t>1
\end{array}\right.
$$

In the pilot, the ASP charges an initial fee, termed $P_{\text {initial, }}$ which pays for installing the RFID-related hardware to make the breakeven point of the ASP's start-up costs

$$
P_{\text {service }}=\frac{\sum_{t=1}^{T} \text { TOC }_{t^{*}}(1+x \%)}{\sum_{t=1}^{T} K+N+M+l_{t}}
$$


The ASP may also charge a service fee, denoted by $P_{\text {service, }}$ after the first installing period. To make a positive profit, we impose a desired proportion of profits, $x \%$, on the operations costs and then divide it by the number of accumulated clients over service periods, $1,2, \ldots$, $T$. The profit is calculated by revenue minus costs

$$
P_{\text {initial }}=\frac{15542500}{60+90+45+9200}=1658
$$

Profit $=P_{\text {initial }}$. Newly Adopting Members $+P_{\text {service }}$. Accumulated Members $-T C$

Supplier, food manufacturers (including transportation) and DCs adopt the RFID technology in period 1 followed by retailers from $I_{1}$ to $I_{T}$ in $T$ periods. We note that in each period the ASP only charges an initial fee to newly adopting members. Those adopting the RFID in preceding periods are charged a service fee in each period. The profit of the ASP in each period can be stated as:

\section{Numerical Experiment}

$$
\text { Profit }=\left\{\begin{array}{lr}
P_{\text {initial }}\left(K+N+M+l_{t}\right)-T C_{t} & t=1 \\
P_{\text {initial }}\left(l_{t}-l_{t-1}\right)+P_{\text {gervice }}\left(K+N+M+l_{t-1}\right)-T C_{t} & t=2, \ldots, T \\
P_{\text {service }}(K+N+M+L)-T C_{t} & t>T
\end{array}\right.
$$

Hong I-Hsuan et al (2011) recorded the number of four typical product categories available in convenience stores: beverage, instant, packaged and frozen. They also take samples from five different retailer locations to estimate the consumption of RFID tags the total consumption of the annual number of tags can be approximated as 6.420.496. 000 tags. This tags defines as the tags that are needed foe each item of the product. So, the estimated tags needed will be accumulated along with the reader and other installment's tools.

The next sections discuss 4, 5, 6 and 7 year promotion schemes for the pilot project. To record the complete data throughout the food supply chain, the manufacturers and DCs may need to adopt RFID technology at the onset of the 4, 5, 6 or 7 year promotion scheme. We assume that supplier, food manufacturers, transportation (inbound and outbound) and DCs install RFID hardware in Year 1 and retailers participate in Years 1-7.

\section{ASP initial fee}

The annual expenditure including start-up and operations costs are predicted. The major part of operations cost is salaries. These salaries are for the personnel plan that included in this project. We approximate the personnel plan and total payroll as shown in Table 3 (the numbers are in New Taiwan Dollars (NTD)).

Table 3

\begin{tabular}{cccl} 
Personnel Plan for the pilot project & (Hong l-Hsuan et al (2011)) \\
\hline Year 1 & Year 2 & Year 3 & Payroll \\
& & & (year/person) in \\
& & NTD \\
\hline
\end{tabular}


Business Model Financially ...

\begin{tabular}{lllll}
\hline President & 1 & 1 & 1 & 1147500 \\
\hline Vice President & 0 & 1 & 1 & 675000 \\
\hline Manager & 1 & 1 & 2 & 810000 \\
\hline IT engineer & 6 & 9 & 10 & 607500 \\
\hline Accountant & 2 & 2 & 4 & 472500 \\
\hline Sales & 6 & 8 & 10 & 337500 \\
\hline Technician & 4 & 6 & 7 & 405000 \\
\hline $\begin{array}{l}\text { Total } \\
\text { personnel }\end{array}$ & 20 & 28 & 35 & \\
\hline Total payroll & 10192500 & 14175000 & 17617500 & \\
\hline
\end{tabular}

Table 4 shows the details of the start-up costs, which are 15,542,500. We apply the pricing method illustrated in the previous section. We take the value of the total start-up costs TSC as 15,542,500, the number of supplier $K$ as 60 , food manufacturers and transportation $M$ as 90 , the number of DCs $N$ as 45 and the number of retailers $L$ as 9200 , respectively. The total of the members is 9395 at the end of each scheme. The initial fee is calculated as follows

Table 4

Estimated expenditure (in thousand NTD)

\begin{tabular}{lllll}
\hline & Year 1 & Year 2 & Year 3 & Year 4 \\
\hline Start-up costs & & & \\
\hline Technology transfer fees & 10120,5 & & & \\
\hline Deposit for office rent & 546 & & & \\
\hline Interior decoration & 1800 & & & \\
\hline Office furniture and comp & 3054,5 & & & \\
\hline Office supplies & 52 & & & \\
\hline Total & 15542,5 & & & \\
\hline Operations costs & & & & \\
\hline Payroll & 10192,5 & 14175 & 17617,5 & 17617,5 \\
\hline Insurance & 2400 & 2400 & 2400 & 2400 \\
\hline Office rent & 3480 & 3480 & 3480 & 3480 \\
\hline Utilities & 300 & 300 & 300 & 300 \\
\hline Miscellaneous & 340 & 340 & 340 & 340 \\
\hline Total & 16712,5 & 20695 & 24137,5 & 24137,5 \\
\hline Total Costs & 32255 & 20695 & 24137,5 & 24137,5 \\
\hline
\end{tabular}

\section{ASP service fee for four scheme}

The ASP also charges an annual service fee after installation. The pricing strategy of the service fee for the four promotion schemes is discussed below 
The technology transfer fee comprises the maximum part in Year 1. The ASP's total expenditure includes the start-up and operations costs in Year 1 and only the operations costs thereafter. For the four year scheme, note that the total cost is 24,137,500 after Year 3. Suppose that the ASP is expected to earn a $20 \%$ profit. Given that the accumulated numbers of installing clients are 2075, 4675, 7275 and 9395, the service price, as shown in $(8)$, is

$$
P_{\text {service }}=\frac{(16712500+20695000+24137500 \cdot 2) \cdot(120 \%)}{2075+4675+7275+9395}=3436
$$

Then, for the 5, 6, 7 -year promotion scheme eventually serves the same number of clients, we let it adopt the identical personnel plan. The total cost in Years 5, 6, and 7 are the same as the cost in Year 4 of the 4-year promotion scheme. Again, suppose that the ASP is expected to earn a $20 \%$ profit. Given that the accumulated numbers of installing clients are $1800,3700,5700,7600,9395$ for 5 year scheme. The accumulated numbers of installing clients are 1375, 2675, 4675, 6675, 7975 and 9395 for the 6 year scheme, and 800, 2000, $3700,5700,7400,8600$, and 9395 accumulation are for the 7 year scheme, so the service price for each year scheme are:

$$
\begin{gathered}
P_{\text {service }}=\frac{(16712500+20695000+24137500 \cdot 3) \cdot(120 \%)}{1800+3700+5700+7600+9395}=3882 \\
P_{\text {service }}=\frac{(16712500+20695000+24137500 \cdot 4) \cdot(120 \%)}{1375+2675+4675+6675+7975+9395}=4224 \\
P_{\text {service }}=\frac{(16712500+20695000+24137500 \cdot 5) \cdot(120 \%)}{800+2000+3700+5700+7400+8600+9395}=4452
\end{gathered}
$$

Thus, $P_{\text {initial }}=1658$ in Year 1 for all scheme and $P_{\text {service }}$ are 3436, 3882, 4224, 4552 for 4, 5, 6, and 7 year scheme. These $P_{\text {service }}$ are charged in Year 2 and thereafter. Note that $P_{\text {initial }}$ and $P_{\text {service }}$ shown in the paper are rounded to the closest integer number.

\section{Profit Analysis}

Next, we estimate the profits for four promotion schemes based on (10). For 4 year promotion scheme, year 1's profit is

Profit $_{1}=1658.2075-32285500=-28846014$

Year 2 to 4 are as follows:

Profit $_{2}=(1658.2600+3436.2075)-20695000=-9255823$

Profit $_{3}=(1658.2600+3436.4675)-24137500=-3765025$

Profit $_{4}=(1658.2600+3436.7275)-24137500=4372633$

And after year 4 , the profit will be

Profit $_{t}=3426.9395-241137500=8142629, t>4$

The tabulation of the profit for all scheme are shown in Table 5 and Table 6 
Table 5

The member of the scheme each year

\begin{tabular}{lllllllll}
\hline Scheme & 4-year & \multicolumn{3}{c}{ 5-year } & \multicolumn{3}{c}{ 6-year } & 7-year \\
\hline Year & $\begin{array}{l}\text { Total } \\
\text { member }\end{array}$ & $\begin{array}{l}\text { new } \\
\text { member }\end{array}$ & $\begin{array}{l}\text { Total } \\
\text { member }\end{array}$ & $\begin{array}{l}\text { new } \\
\text { member }\end{array}$ & $\begin{array}{l}\text { Total } \\
\text { member }\end{array}$ & $\begin{array}{l}\text { new } \\
\text { member }\end{array}$ & $\begin{array}{l}\text { Total } \\
\text { member }\end{array}$ & $\begin{array}{l}\text { new } \\
\text { member }\end{array}$ \\
\hline year $\mathbf{1}$ & 2075 & 2075 & 1800 & 1800 & 1375 & 1375 & 800 & 800 \\
\hline year 2 & 4675 & 2600 & 3700 & 1900 & 2675 & 1300 & 2000 & 1200 \\
\hline year 3 & 7275 & 2600 & 5700 & 2000 & 4675 & 2000 & 3700 & 1700 \\
\hline year 4 & 9395 & 2120 & 7600 & 1900 & 6675 & 2000 & 5700 & 2000 \\
\hline year 5 & 9395 & N/A & 9395 & 1795 & 7975 & 1300 & 7400 & 1700 \\
\hline year 6 & 9395 & N/A & 9395 & N/A & 9395 & 1420 & 8600 & 1200 \\
\hline year 7 & 9395 & N/A & 9395 & N/A & 9395 & N/A & 9395 & 795 \\
\hline
\end{tabular}

Table

6 Summarize profit each scheme

\begin{tabular}{lllll}
\hline Scheme & 4-year & 5-year & 6-year & 7-year \\
\hline Initial Fee & 1658 & 1658 & 1658 & 1658 \\
\hline Service Fee & 3436 & 3882 & 4224 & 4452 \\
\hline year 1 & -28846014 & -29301849 & $-30006322,2$ & $-30959432,94$ \\
\hline year 2 & -9255823 & -10559241 & $-12733067,5$ & $-15144502,42$ \\
\hline year 3 & -3765025 & -6461503 & $-9524934,74$ & $-12416115,02$ \\
\hline year 4 & 4372633 & 1135349 & $-1078282,31$ & $-4350871,259$ \\
\hline year 5 & 8142629 & 8335782 & 6208061,439 & 4055346,08 \\
\hline year 6 & 8142629 & 12327362 & 11897295,57 & 10794522,78 \\
\hline year 7 & 8142629 & 12327362 & 11897295,57 & 39602796,83 \\
\hline
\end{tabular}

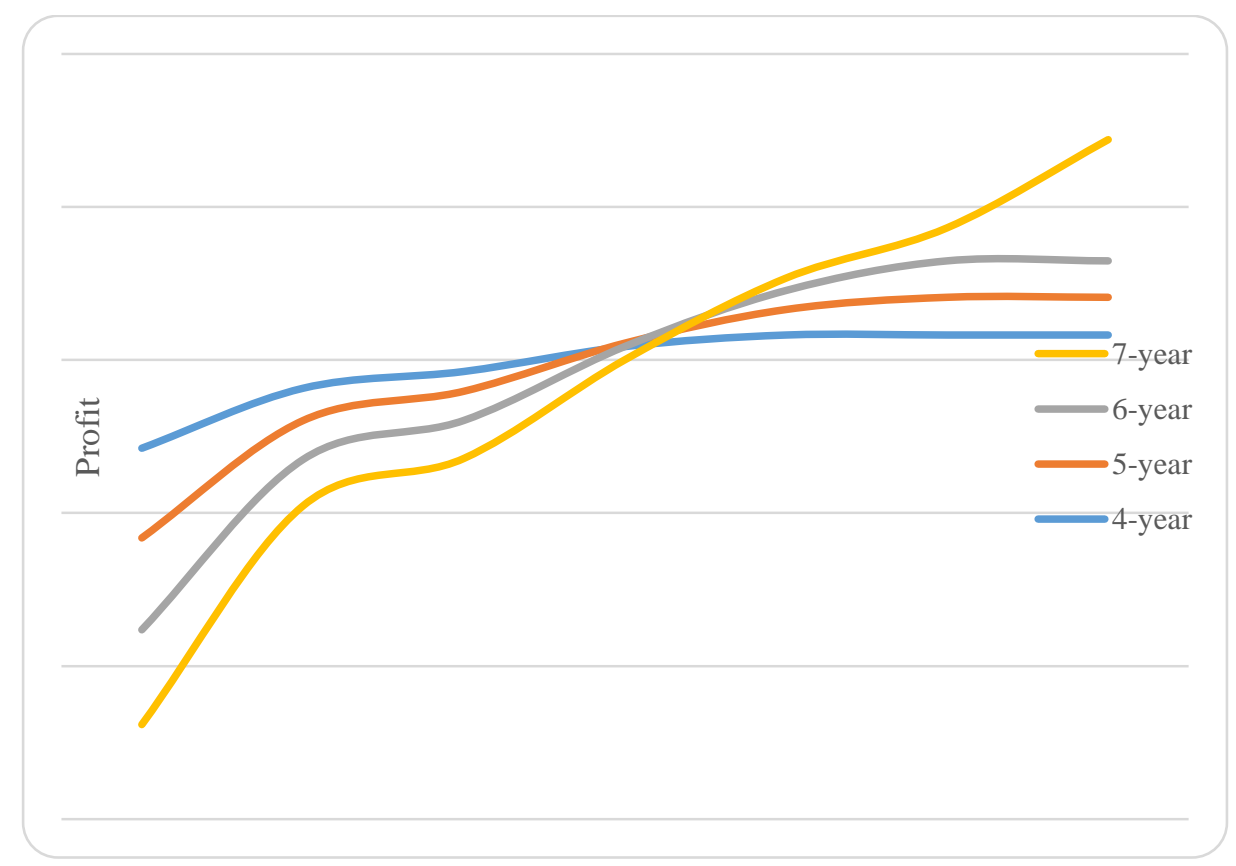

Figure 2

Profit Each Scheme 
Table 6 shows a positive profit in all promotion schemes after 4 -year. We note the following insights. The initial fee of the four schemes is the same, but the service fee of the 5,6, and 7-year scheme is higher than the 4-year scheme since the 5, 6, and 7-year scheme has a relatively higher annual personnel cost. Because of a larger number of installing members in the beginning of the 4-year promotion scheme, its profits are greater than the other schemes in Years 1-7. However, as shown in Figure 2 when the installing number reaches the same level for all schemes, since the 7-year scheme has a higher service fee, the profits of the 7 the greatest than the other scheme from 7-year.

\section{CONCLUSION}

In recent years Muslim are more focused on Halal food traceability systems which provide visibility of transaction processes to members of food supply chains and customers. With the implementation of RFID technology, Halal food traceability systems can become more reliable and efficient. This paper proposes a framework for promoting a Halal food traceability system and analyzes the profits and costs associated with RFID implementation for a convenience store supply chain of supplier, transportation, manufacturers, DCs and retailers. We also develop a pricing strategy in which an ASP charges an initial fee for installing RFID in the first year and an annual service fee for technical support thereafter.

For the manufacturer, supplier, DCs, and retailer, halal is a dynamic market that should not be ignored. The rate of growth driven by consumer demand for high quality halal products worldwide is a market to be taken seriously. By Halal Supply Chain integrity, the brand of halal will be more trustworthy and become advantage to the Muslim customers. Since, the integrity of "halal" itself is assured from the supplier to the remains intact throughout the whole process of the logistics and supply chain. The usage of RFID also give benefits to the economic perspective, although we need investments in the beginning, but then the positif profit will be obtained due to the documentation of the demand and the halal guarantee as such of a promising strategy for responsiveness of the demand and the halal brand. The whole supply chain will not get overstock and stockout respectively, while the customer always buy the trusted "halal" food and beverages in their daily consumption.

We suggest that future research consider using another growth function, such as the normal distribution, to predict the number of members who might conceivably adopt RFID technology. For the variable cost of the tags and reader should be considered. Furthermore, global food safety policies stipulated by governments typically are followed by a series of regulations which many countries then implement due to increasing of the Halal food demand. 


\section{REFERENCES}

Abdul Talib, H.H., Mohd Ali, KA., \& Jamaludin, K.R. (2008). 'Quality Assurance in Halal Food Manufacturing in Malaysia: A Preliminary Study', paper presented to International Conference on Mechanical and Manufacturing Engineering (ICME2008), Johor Bahru, Malaysia.

Bahrudin, .SS.M., Illyas, M.I., \& Desa, M.I. (2011). Tracking and Tracing Technology for Halal Product Integrity over the Supply Chain. Paper presented to International Conference on Electrical Engineering and Informatics 17-19 July 2011, Bandung, Indonesia

Belkhatir, M., Bala, S., \& Belkhatir, N. (2009). 'Business process re-engineering in supply chains examining the case of the expanding Halal industry', Milan

Beulens, A. J. M., D.-F. Broens, et al. (2005). "Food safety and transparency in food chains and networks Relationships and challenges." Food Control 16: 481-486.

Gandino, F., Montrucchio, B., Rebaudengo, M., \& Sanchez, E.R. (2007). Analysis of an RFIDbased information system for tracking and tracing in an agri-food chain. Proceedings of the First Annual RFID Eurasia, 1-6.

Jan, L. R. (2012). Marketing halal: Creating new economy, new wealth. Petaling Jaya, Malaysia: MPH Group.

Hong, IH, Dang, Jr-F, Tsai, YH, Liu, CS, Lee, Wt, Wang, ML, \& Chen, PC. (2011). "An RFID application in the food supply chain: A case study of convenience stores in Taiwan". Journal of Food Engineering. vol 106, pp 119-126

Kettani H. (2010). World Muslim Population. (2010). Proceedings of the 8th Hawaii International Conference on Arts and Humanities, Honolulu, Hawaii, January.

Lodhi, A. H., H. U. Ltd, et al. (2010). Understanding Halal Food Supply Chain, HFRC UK, Limited.

McMeekin, T.A., Baranyi, J., Bowman, J., Dalgaard, P., Kirk, M., Ross, T., Schmid, S., \& Zwietering, M.H. (2006). Information systems in food safety management. International Journal of Food Microbiology 112, pp 181-194.

Meuwissen, M.P.M., Velthuis, A.G.J., Hogeveen, H., \& Huirne, B.M. (2003). Traceability and certification in meat supply chains. Journal of Agribusiness 21, pp 167-181.

Balakrishnan, N. (1992). Handbook of the Logistic Distribution. Marcel Dekker, Inc., New York. 
Muhammad NM., Isa, FMd., Kifli BC. (2011). Positioning Malaysia as Halal-Hub: Integration Role of Supply Chain Strategy and Halal Assurance System. Asian social science. vol 5, no 7

Norton, J.A., Bass, F.M. (1987). A diffusion theory model of adoption and substitution for successive generations of high-technology products. Management Science. Vol 33, 1069-1086.

Rogers, E.M., (1995). Diffusion of Innovations, 4th ed. New York : Free Press.

Spiegel, Fels-Klerx, P. Sterrenburg, S.M.van Ruth, I.M.J.Scholtens-Toma., \& E.J. Kok. (2012). Halal assurance in food supply chains: Verification of halal certificates using audits and laboratory analysis. Trends in Food Science \& Technology. vol 27. pp 109-119

Tajima, M. (2007). Strategic value of RFID in supply chain management. Journal of Purchasing and Supply Management 13, pp 261-273.

Tieman, M., Jack, G.A.J., Vorst V.D. \& Ghazali, M.C. (2012). Principles in Halal supply chain management. Journal of Islamic Marketing,3(3), pp 217-243.

Tieman, M, Ghazali, MC. (2014). Halal control activities and assurance activities in halal food logistics. Social and Bahavioral Sciences. Vol 121, pp 44-57

Wamba, S.F., Lefebvre, L.A., Bendavid, Y., Lefebvre, É., 2008. Exploring the impact of RFID technology and the EPC network on mobile B2B eCommerce: a case study in the retail industry. International Journal of Production Economics 112, 614-629.

Yousef D. K., UAE: Halal food numbers look tasty. (2010). Size of global Muslim population creates significant customerbase, [Online]. Available:http://gulfnews.com/business/general/halalfood-numbers-look-tasty1.679007

Zulfakar, M.H., Anuar, M.M., \& Talib, M. S. (2012). Conceptual Framework on Halal Food Supply Chain Integrity Enhancement. Paper presenter to International Halal Conference, Putra World Trade Centre Kuala Lumpur, Malaysia, 4-5 September 2012 